\title{
COUNTERACTING EFFECTS OF A LONG-LASTING ELECTRICAL POWER FAILURE IN THE AREA OF LARGE CITIES. A CASE STUDY FOR THE MUNICIPALITY OF THE CITY OF SZCZECIN
}

\begin{abstract}
The author's intention is to show the impact of experience from a specific crisis situation and results brought about by it - in particular a long-lasting and extensive power outage - affecting the activity of entities obliged in terms of prevention of such threats as well as being prepared to respond in the event of their occurrence. Due to the specified research subject, the reflections focus on the activity of the bodies of the Municipality of the City of Szczecin and cooperation with other entities for the prevention of selected threats, with particular emphasis on after-effects of an extensive electrical power failure. The paper refers to applicable laws and official documents addressing competences and tasks assigned to these bodies as part of crisis management, including the protection of critical infrastructure. A lot of attention was given primarily to issues related to organizing, conducting and coordinating training and exercises in the field of crisis management with the participation of representatives of various entities and circles, including academic ones. It mainly presented the conclusions and recommendations formulated on the basis of the exercise carried out on 19 March 2018: "Operation of the City Crisis Management Team in the event of an electrical power failure", codenamed "Energy 2018". The preparation and conducting of the exercise resulted from the need to explain the problematic situation expressed in the following question: does facing real effects of a blackout ${ }^{2}$ affect qualitative changes in terms of preparation of obligated entities in the event of a similar crisis situation?
\end{abstract}

Keywords: crisis management, critical infrastructure, electrical power failure, territorial selfgovernment, Municipality of the City of Szczecin

\section{INTRODUCTION}

Currently, the functioning of every country, its stability and development, as well as the existence of its residents - regardless whether it concerns highly-developed countries or

\footnotetext{
${ }^{1}$ Cezary Guźniczak, PhD, assistant professor in the Faculty of Humanities of the University of Szczecin, 71-017 Szczecin, ul. Krakowska 71-79; e-mail: c.guzniczak@wp.pl. ORCID: 0000-0003-2344$-8281$.

Dr Cezary Guźniczak, adiunkt na Wydziale Humanistycznym Uniwersytetu Szczecińskiego, 71-017 Szczecin, ul. Krakowska 71-79, e-mail: c.guzniczak@wp.pl. ORCID: 0000-0003-2344-8281 .

2 This applies to the Szczecin blackout of 8 April 2008.
} 
those at a lower level of development - are dependent on electricity ${ }^{3}$. Sustainable and continuous supply of electricity constitutes the state's economic strength and international position. Moreover they determine its security in all aspects and give the feeling of safety and security to all people residing in its territory. Energy independence guarantees the state and the society as well as all individuals uninterrupted advancement and strengthens their activity in various spheres of life.

In order to secure energy security contemporary states are carrying out - less or more effectively - activities which in Poland are called state energy policy. The aims of this policy include: ensuring energy security of the state, increasing economy's competitiveness and its energy efficiency as well as the protection of the environment ${ }^{4}$. The implementation of the aims should be an added value in creating conditions for the country's sustainable development, including harmonizing interests of energy companies and fuel and energy recipients; also, an economical and rational usage of fuel and energy, while taking into account requirements of environmental protection and fulfilling obligations resulting from international agreements ${ }^{5}$.

Continuous development of the system of energy supply which the legislator aggregated into critical infrastructure gains particular importance for the effective implementation of the country's energy policy goals ${ }^{6}$.

The author's intention is to show the impact of experience from a specific crisis situation and results brought about by it - in particular long-lasting and extensive power outage affecting the activity of entities obliged in terms of prevention of such threats as well as being prepared to respond in the event of their occurrence.

\section{ELECTRICITY - A SENSITIVE LINK IN CRITICAL INFRASTRUCTURE SYSTEMS. SELECTED ELECTRICAL POWER DISASTERS IN THE WORLD}

Referring to the statement formulated in the introduction saying that the functioning and flourishing of contemporary countries and their economies, as well as the existence and development of almost all of the people in the world are dependent on electricity, one needs to stress that lack of electrical power effectively limits the capability of uninterrupted and

\footnotetext{
${ }^{3}$ Electricity is the basic source of energy for industry and households. Due to the degree of the economy's, and in particular household consumers' dependency on electricity, a power cut may cause significant damage, especially in large urban centres. Electricity's characteristic features, such as the impossibility to store quantities that can meet even the short-term demand of customers and the extremely short time between generation and consumption result in the electrical power system not having inertia that allows any interruptions in supply without noticeable consequences for recipients. National Crisis Management Plan, part B, NCMP, p. 204. Source: http://rcb.gov.pl/krajowyplan-zarzadzania-kryzysowego/ (access: 01.08.2018).

4 See Article 13 of the Act of 10 April 1997 Energy law (consolidated text, Dz. U. of 2018 item 755 as amended) - hereinafter: EL.

${ }^{5}$ Cf. Article 1 EL.

${ }^{6}$ Critical infrastructure - systems and mutually bound functional objects contained therein, including constructions, facilities, installations and services of key importance to the security of the state and its citizens as well as serving to ensure the efficient functioning of public administration authorities, institutions and enterprises. See Article 3 subsection 2 of the Act of 26 April 2007 on crisis management (consolidated text, Dz. U. of 2017 item 209 as amended) - hereinafter: CMA.
} 
effective operation of the remaining statutorily defined systems of critical infrastructure ${ }^{7}$. Therefore, one needs to realize that in the overall - let us call it - national critical infrastructure system electricity plays a decisive role. The effective running of this system and the subsystems integrated in it is not possible without ensuring functionality, continuity of operation and integrity of the electrical power potential. To prove the truth of the abovementioned conclusion it is sufficient to quote several pieces of media messages on the consequences of a sudden lack of electrical power supply on the area of entire countries or large cities in various parts of the world. Negative consequences of these events left a mark not only on residents of numerous places but also caused irregularities in the functioning of certain countries' economies ${ }^{8}$. The effects of the abovementioned failures were different, depending on their causes and duration as well as territorial reach. Nevertheless, in each case a "domino effect" took place as along with the occurrence of a fundamental threat in the form of lack of electricity, secondary threats occurred as a snowball effect, which were the consequence of disturbances in the functionality of further critical infrastructure systems.

${ }^{7}$ Critical infrastructure includes the following systems: energy, fuel and energy resources supply; communication; tele-information network; financial; food supply; water supply; health protection; transportation; rescue; systems ensuring the continuity of public administration activities; production, storing and use of chemical and radioactive substances, including pipelines for dangerous substances. Ibidem.

8 The North American blackout of 1965 was the first such a serious power failure in the world. The cause was human error that happened long before the event itself. The possibility of overloading of one of the key lines was not foreseen. When the overload occurred, the rest started falling like dominoes. To avoid damage, all power plants in the area were gradually disconnected. For 12 hours Ontario in Canada and the US states of Connecticut, Massachusetts, New Hampshire, Rhode Island, Vermont, New York and New Jersey were without electricity. 30 million people were affected by the failure. In Toronto, there was total communication paralysis. Traffic lights did not work, there was chaos on the roads. People got stuck in the elevators or the subway. Another blackout of 2003 started in New York. It was from there that the surplus power came, which caused further shutdowns in the northeastern states. The transmission network in Ontario also failed. As established, one of the reasons was the increased demand for energy on this unlucky day. The air temperature was over 30 degrees Celsius, which meant that all cooling devices worked at full speed. Also in 2003, an Italian blackout occurred, resulting in as many as 56 million people drowned in the dark for 12 hours. The failure was related to damage done to the line between Italy and Switzerland during a storm. As a result of the cascading effect, a line leading from France was soon also switched off. Then the Italian network finally collapsed. Thousands of people got stuck in the subway. Thirty thousand people were stuck on trains. All flights were canceled. After about three hours, power was being restored in the north of Italy. Problems with electricity supply lasted a few more days. A 2009 blackout severely hit Paraguay and Brazil. The reason was the failure of three transformers located on one of the key power lines. The storm caused a short-circuit which rapidly cut off and shut down the Itaipu Dam - a hydroelectric power station with a power comparable to that of the Three Gorges Dam. 60 million people were cut off from electricity. There was no electricity in 18 of the 26 states of Brazil and all of Paraguay. After 6 hours the effects of the failure were tamed and the power supply restored. Nevertheless, thousands of accidents occurred on darkened roads, and many passengers were stuck on trains and in the subway. Source: http://buzz.gazeta.pl/buzz/ 56,163510,9829216,TOP_6_najwiekszych_blackoutow_w_historii_Miliony.html (access: 28.07. 2018). 


\section{SZCZECIN BLACKOUT OF 8 APRIL 2008 - CAUSES, CONSEQUENCES, REFLECTIONS}

Due to the research subject matter defined in the title, as well as objectively existing research capabilities (in particular limited access to reliable source materials), further reflections address the issues of a long-lasting power failure in the area of Szczecin agglomeration. It was key here to present the activity of the territorial self-government bodies of the Municipality of the City of Szczecin in terms of counteracting various threats, including negative effects of a long-lasting lack of electricity.

An electrical power disaster called "Blackout", which covered the Szczecin municipality and part of territories of neighbouring poviats ${ }^{9}$, took place on 8 April 2008. The cause of the failure was the breaking of main and reserve lines (two of which were 220 thousand V) supplying the Szczecin agglomeration ${ }^{10}$. As a result, connectivity was interrupted and paralysis of public and railway transport occurred. The lack of power immobilized petrol stations as a result of which it was impossible to refuel. Difficulties in supplying water were observed, offices and shops were not working, cash machines were not functioning, and neither were traffic lights. Due to the lack of continuity of electricity supply hospitals worked in an A\&E mode. Operating theatres were put into work only in life-threatening cases $^{11}$. To sum up, due to the large-scale electrical power failure the functionality of the following city critical infrastructure systems was seriously disrupted for at least a few hours: energy and fuel supply; communications and IT networks; finance; food and water supply; health care and rescue services; transport; those ensuring continuity of operation of public administration; production, warehousing, storage and use of chemical substances.

Still on 8 April, as a result of actions taken, Szczecin's electricity services supported by teams from Gorzów Wielkopolski, Zielona Góra and Bydgoszcz made it possible for approx. $80 \%$ of residents to have electricity back on that same day in the evening. The

\footnotetext{
9 "Cities that were left without electricity supply: Szczecin, Police, Nowe Warpno, Trzebież, Goleniów, Maszewo, Nowogard, Stargard Szczeciński, Świnoujście, Międzyzdroje, Wolin, Kamień Pomorski, Trzebiatów, Resko, Płoty, Gryfice, Golczewo, Dobra Nowogardzka. It is estimated that on 8 April 2008 in the morning hours around 512 thousand of residents of the voivodeship had no electricity supply". Information provided as part of the interview conducted on 24 July 2018 with dr Szczepan Stempiński, the President of the City of Szczecin's Plenipotentiary for Security, based on the content contained in the report prepared by the team for the investigation of the causes and effects of the electrical power disaster, which operated under the leadership of the West Pomeranian Voivode.

10 "extremely unfavorable weather conditions are the most important cause of the disaster: the rime overloads of power line cables exceeded by at least a dozen or so percent the standard catastrophic values adopted in the calculations. Abundant rainfall in the period preceding the failure was an additional factor affecting the course of events and the extent of damage. This precipitation caused an increase in the level of groundwater which resulted in softening of the ground. This could have resulted in decreased stability of the sitting of both the power lines poles and the tree lines growing near them". Information provided as part of the interview conducted on 24 July 2018 with dr Szczepan Stempiński...

11 The formulated content is a summary of press releases of 9 April 2008, published in the following dailies: "Gazeta Wyborcza - Szczecin", articles such as "Śnieg ciężki, jak ołów" [Snow as heavy as lead], "Szczecin bez prądu" [Szczecin without electricity]; "Expres Ilustrowany", article "Szczecin bez prądu!" [Szczecin without electricity!]; "Expres Bydgoski”, article "Gigantyczna awaria rozłożyła cały Szczecin” [A gigantic failure paralyzed entire Szczecin].
} 
electricity supply was also resumed at Zakłady Chemiczne Police (chemical plant), with full operation of the installation taking a dozen or so hours. The next day ( 9 April) in the morning the urban heating system was back on and tramway transportation was gradually resuming ${ }^{12}$. Nevertheless, repair operations - restoring the power supply on the whole area affected by the failure - took another few weeks, whereas the modernization of the transmission networks took several years and it is not finished yet ${ }^{13}$.

Summing up the negative consequences of the Szczecin blackout, it needs to be highlighted that they were of a purely economic nature as the most severe - biological - losses were avoided. The table below presents a compilation of combined costs of the rescue operation, costs incurred by surveyed plants, companies as well as hospitals, poviats and communes.

Table 1. Costs of the Szczecin electrical power disaster in 2008

\begin{tabular}{|l|l|}
\hline Costs of restoring/rescue operations & PLN 829,0731.34 \\
\hline Costs incurred by plants, companies, hospitals & PLN 45,172,424.12 \\
\hline $\begin{array}{l}\text { Costs incurred by poviats and communes during the electrical power } \\
\text { disaster }\end{array}$ & PLN 979,468.41 \\
\hline TOTAL COSTS $^{14}$ & PLN 46,981,623.87 \\
\hline
\end{tabular}

Source: author's own compilation based on information provided as part of the interview conducted on 24 July 2018 with dr Szczepan Stempiński, the President of the City of Szczecin's Plenipotentiary for Security.

The disaster described above shows that despite the obvious progress in the development of science, the creation of modern devices and increasingly durable and resistant materials and the development of information technology, etc., we still have to face the limitations and difficulties in terms of protection against both natural and civilization hazards. It should also be borne in mind that the source of a number of civilization threats lies in the insufficiently protected and imperfect critical infrastructure, which is the result of humanity's quest to improve the quality of life, including a higher level of security. It is worth noting a paradox here - a kind of scornful chuckle of the present day. Well, despite the unquestionable fact that together with civilization development the catalogue of solutions and services positively influencing people's comfort of life and security is being enriched, the processes and

12 Ibidem.

13 See information published on the cire.pl portal, Centrum Informacji o Rynku Energii [Energy Market Information Centre], Inwestycje Enei Operator zminimalizowały ryzyko powtórki szczecińskiego blackoutu [Enea Operator's investments minimized the risk of a repeat of the Szczecin blackout]. Source: https://www.cire.pl/item,161581,1,0,0,0,0,0,inwestycje-enei-operator-zminimalizowaly-ryzyko-powtorki-szczecinskiego-blackoutu.html (access: 02.08.2018)

14 "The specified amount should be increased by the two million zloty costs incurred by entities not included in this study and the five million zloty costs incurred by other companies. The total costs would amount to PLN 55.5 million. This amount does not include losses and costs incurred by residents and farmers. The estimated cost of electricity undelivered to Zachodniopomorskie residents during the April breakdown was calculated to range between PLN 63.485 million and PLN 95.407 million". Information provided as part of the interview conducted on 24 July 2018 with dr Szczepan Stempiński, the President of the City of Szczecin's Plenipotentiary for Security (...)". 
effects of the advancement often generate new threats to real safety and security. Moreover, they weaken people's (individual's, entire societies') ability to deal with difficult, and most of all extreme situations. There is no doubt that the efficiency of individual or collective activity on a daily basis, and in particular in situations of danger, is determined by the possibilities of stakeholders' using modern tools or life facilities, such as: running water, heating, electricity, satellite communications and others. We are dealing here with a classical oxymoron where civilization development strengthens security and at the same time threatens humanity both in the individual dimension and one of entire societies. By creating modernity and giving comfort it weakens individual and collective primary ability to do well in the event of sudden difficulties. Mostly in circumstances largely diverting from the level of life acknowledged by given societies or from universally accepted standards of safety and security ${ }^{15}$. Indeed, as any other thesis, in order for its truth to be recognized it should be backed by evidence. It seems, however, that the multitude of media reports on daily tragic events in the world together with quantitative and qualitative data concerning biological, economic and social losses are more than telling and sufficiently prove the validity of the above-mentioned conclusion.

\section{ACTIVITIES OF THE BODIES OF THE MUNICIPALITY OF THE CITY OF SZCZECIN FOR THE SAFETY AND SECURITY OF RESIDENTS, IN PARTICULAR IN THE EVENT OF AN ELECTRICAL POWER DISASTER}

It had been exactly 10 years on 8 April 2018 since the Szczecin blackout happened. This failure - although not the only one in Poland - due to its complex causes and extensive effects was the subject of many studies and analyses. Although it is already in the past, it continues to stimulate practitioners and scientists to work on developing solutions that aim to prevent similar threats and to react when they occur. This is evidenced by, among others, the content of the aforementioned National Crisis Management Plan 2017 (NCMP). It was developed on the basis of and in accordance with the provisions of the Act of 26 April 2007 on crisis management by the Government Security Centre (GSC) ${ }^{16}$. This plan includes, in particular, the characteristics of threats, their potential causes and a description presenting the likely adverse effects of a given threat on people, the environment, property and infrastructure, as well as an assessment of their risk of occurrence, including those concerning critical infrastructure. Referring to the system of production, transmission or distribution of electricity, the authors of NCMP indicate that disturbances in this system may be caused by spontaneous damage to network elements, the actions of third parties or the impact of extreme atmospheric conditions ${ }^{17}$.

15 Article 5 and Article 11 section 2 subsection 1b CMA.

${ }^{16}$ National Crisis Management Plan (hereinafter: NCMP), part A. Source: http://rcb.gov.pl/krajowyplan-zarzadzania-kryzysowego/ (access: 01.08.2018)

17 The NCMP characterizes four types of causes and types of disturbances in the energy system: system failure - a traffic event as a result of which part of the National Power System (NPS) with a value of more than $5 \%$ of the current power demand in the NPC is taken out of synchronic traffic; network failure - a traffic event as a result of which part of the NPS with a value of not more than $5 \%$ of the current power demand in the NPS is taken out of synchronic traffic; blackout, an extensive power failure - voltage loss in the NPS power network in a large area as a result of the occurrence of a sequence of several random events (network failures, power plant shutdowns, 
In the light of the above as well as the previously presented facts, the assurance of Krzysztof Tchórzewski, the Minister for Energy, sounds definitely surreal: "We already have a situation in which we are not at risk of the so-called blackout. A blackout occurs when networks are overloaded and power plants turn off automatically one by one" ${ }^{18}$. Nevertheless, it seems more reasonable that just like in the case of a modern state where its stability and development depends on many factors, and above all on avoiding and reducing risk, using opportunities and effectively responding to challenges - this principle also applies in the field of energy. By traversing the Latin motto si vis pacem, para bellum ${ }^{19}$, it was possible to formulate the following rule referring to crisis prevention, or more broadly to state activity in the field of crisis management ${ }^{20}$ : if you want to avoid the consequences of a crisis situation (here: caused by a lack of electricity), get ready for such an eventuality and prepare alternative solutions. Especially that such conduct is fully rational and also forms part of stages of the said crisis management prescribed by law ${ }^{21}$.

It is assumed so by the bodies of the territorial self-government of the City of Szczecin which aim to identify contemporary determinants of security and to cooperate in this area with, among others, the University of Szczecin. In practice - which needs to be emphasized - during planned exercises and training sessions subordinate units and cooperating services undertake the task of estimating security, including defining opportunities and threats as well as revealing strengths and weaknesses. The consequences include amendments to plans as well as the development of new procedures aiming to benefit from the opportunities to avoid and reduce risks. Cooperation, as already emphasized, is also based on the Szczecin academic potential. It is worth noting that just like the representatives of the territorial selfgovernment and of Szczecin services actively support the process of student education and research activity of the University of Szczecin (US), the academic community also actively participates in activities for the safety and security of the self-governing community of the Szczecin municipality. It is worth noting that in years 2016-2018 the research and teaching staff were initiators and co-organizers of a number of projects, including practical command post exercises codenamed "Widzowie" ["Spectators"] under which the obliged services took specific actions in connection with a fire hazard and a hostage situation. The project was carried out on 23 May 2016 in the Azoty Arena sports hall. Apart from the Police, the

extreme weather conditions, terrorist attack), causing the exceeding of critical values of basic technical parameters of the NPS operation (frequency, voltage) and resulting in automatic disconnection from the NPS power network of system power plants connected in this area; power deficit shortage of generation capacities in the National Power System (NPS). Ibidem, part A, NCMP p. 15. (access: 01.08.2018).

18 Source: https://www.money.pl/gospodarka/wiadomosci/artykul/blackout-w-polsce-tchorzewski, 37,0,2367781.html (access: 28.07.2018).

${ }^{19}$ Lat.: if you want peace, prepare for war, W. Kopaliński, Stownik wyrazów obcych i zwrotów obcojęzycznych, 9th extended edition, Warszawa 1975.

${ }^{20}$ Crisis management is the activity of public administration authorities that constitutes an element of managing the national security management system and consists of: preventing crisis situations, preparing to take control over them by way of planned activities, responding in case of emergencies, removing their effects and reconstructing resources and critical infrastructure. See Article 2 CMA.

${ }^{21}$ Based on the cited legal definition of crisis management and on the basis of selected provisions of the Act of 26 April 2007 on crisis management, the following phases are distinguished: prevention, preparation, response, removal of effects and reconstruction. 
State Fire Service, the Office of the City of Szczecin, etc., students of the US Faculty of Humanities (FH) and students of "uniformed classes" of Szczecin upper secondary schools took part in the exercise ${ }^{22}$. Whereas on 9 February 2017, as part of the cooperation with the Municipal Headquarters of the State Fire Service in Szczecin, a scientific and research experiment was carried out at the "Galeria Kaskada" Shopping Centre in Szczecin. The aim of the experiment was to obtain from the participants their opinions on the solutions applied in the said facility that determine the safety of people staying in its area, in those particular concerning:

- readability of escape signs; whether they allow smooth access to emergency exits;

- communication system; whether it is accessible or complicated, and thus does not positively affect the ease of a person's orientation as to the place in the facility he is at a given moment, as well as in terms of a choice of a route to the place he would like to reach.

The author was the originator and co-organizer of the experiment while the members and the supervisor of the Si vic pacem, para bellum Safety and Military Students Association operating at the US Faculty of Humanities were its participants ${ }^{23}$.

The above and a number of other activities indicate that the activity of self-government bodies and services of the City of Szczecin in the sphere of preparing the potential for the possible occurrence of probable threats is of a continuous nature, and so is the cooperation in this area with the US staff.

It is precisely on the basis of the experiences resulting from the cooperation so far that at the end of 2017 the US Faculty of Humanities' research and teaching staff developed a concept of an exercise, the implementation of which would allow clarification of the following problematic situation: does facing the real effects of a blackou ${ }^{24}$ affect the qualitative changes in terms of preparation of obligated entities in the event of a similar crisis situation? After obtaining the approval of the FH's authorities and the will to proceed with the implementation of the project expressed by the President of the City of Szczecin, the preliminary assumptions were subject to consultation with, among others, representatives of the Department of Crisis Management and Civil Protection of the Office of the City of Szczecin. The following title for the exercise codenamed "Energy 2018" was adopted in the end: "Operation of the City Crisis Management Team in the event of an electrical power failure" and it was agreed that the exercise would aim to improve selected elements of the city crisis management system in the scope of development of tasks for executive units in the crisis response stage. The premises of the Research Workshop on the Safety of Selfgoverning Communities, located in the US Faculty of Humanities' Interactive Centre of Communication and Social Research was assigned to be the place of the exercise ${ }^{25}$.

${ }^{22}$ More in Działania obowiąanych podmiotów w sytuacji kryzysowej podczas masowej imprezy sportowej. Wymiar prawny, teoretyczny i praktyczny na przyktadzie ćwiczenia dowódczo-sztabowego pod kryptonimem ,Widzowie”, eds. C. Guźniczak and Sz. Stempiński, Szczecin 2017.

${ }^{23}$ More in C. Guźniczak, P. Tuzimek, Zapobieganie sytuacjom kryzysowym w nowoczesnych obiektach handlowo-ustugowych. Studium przypadku na przykładzie Centrum Handlowego „Galeria Kaskada” w Szczecinie [in:] Rola i zadania administracji publicznej w zarzadzaniu bezpieczeństwem w Polsce, eds. J. Kisielnicki, T. Płusa, S.J. Rysz, J. Rajchel, K. Rajchel, Rzeszów 2017.

${ }^{24}$ This applies to the Szczecin blackout of 8 April 2008.

${ }^{25}$ More in: Documentation of the urban exercise in the scope of crisis management codenamed "Energy 2018”, approved on 7 March 2018 by Piotr Krzystek, President of the City of Szczecin. Available in the Department of Crisis Management and Civil Protection of the Office of the City of 
At this stage of reflections, before the objectives and the scenario as well as conclusions and recommendations from the course of the exercise are presented, it should be noted that in accordance with the Crisis Management Act, the protection of critical infrastructure $(\mathrm{CI})^{26}$ is the responsibility of its owners and of owner-like possessors and dependent possessors of facilities, installations or devices ${ }^{27}$. This does not mean that starostas, village heads, mayors and presidents of cities as well as subordinate services are exempt from the obligation to conduct activities in the scope of CI protection. These bodies, as well as their subordinate services, are obliged to protect the population exposed to potential consequences of disruption of CI functioning, as well as to provide direct and fastest support to operators in order to protect it. According to the National Critical Infrastructure Protection Program, the task of starostas, village heads, mayors and city presidents is to organize the implementation of tasks in scope of CI protection, in particular ${ }^{28}$ :

- inclusion of tasks related to the protection of critical infrastructure located in the competence area in crisis management plans;

- defining response procedures in the event of destruction or disruption of the functioning of critical infrastructure within the body's sphere of competence;

- protecting the population from the effects of disruption of the functioning of CI using their own resources and the resources of a CI operator;

- support CI operators with technical and human resources at their own disposal or at the disposal of subordinate or supervised services, inspections and guards;

- cooperation with and support of CI operators in the scope of its protection and cooperation in the event of a crisis situation within the body's sphere of competence;

- counteracting threats to life and health of citizens resulting from the disruption of CI functioning with the use of a special-purpose reserve created on the basis of the Act on Crisis Management ${ }^{29}$.

The obligation to implement the above-mentioned tasks by the aforementioned selfgovernment entities results, for example, from the fact that facilities, equipment and installations as well as services constituting CI are physically located in territories of communes, cities and poviats. Nevertheless, it is the operators of a given critical infrastructure that have the best knowledge and conditions to limit the threats to CI, reduce its vulnerability to these threats and choose the most appropriate strategies to minimize the effects of these threats.

Szczecin and in the Research Workshop on the Safety of Self-governing Communities of the US Faculty of Humanities.

${ }^{26}$ Protection of critical infrastructure shall be understood as all steps aimed at ensuring the functionality, continuity and integrity of critical infrastructures in order to prevent threats, risks or vulnerabilities as well as limiting and neutralizing their effects and quick reconstructing the infrastructure in case of failures, attacks and other events disrupting its appropriate functioning. See Article 3 section 3 CMA.

27 More in Article 5b and Article 6 CMA.

${ }^{28}$ National Programme for Critical Infrastructure Protection - consolidated text (PL) (hereinafter: NPCIP). Source: http://rcb.gov.pl/infrastruktura-krytyczna/, pp. 24/48-25/48 (access: 01.08.2018).

${ }^{29}$ A special reserve is created in the budget of the local government unit for the carrying out of crisis management related own tasks in the amount not less than $0.5 \%$ of the current expenditure of the local government unit's budget decreased by investment outlays, expenditure for wages and salaries and similar benefits, as well as expenditure for servicing the debt. See Article 26 section 4 CMA. 
Hence, as previously indicated, the legislator has entrusted them with the obligation to protect CI facilities, equipment, installations and services ${ }^{30}$.

One should be aware that the foreground organizational, legal, technical and educationtraining activities for the power infrastructure discussed in the publication are not the responsibility of the bodies of Szczecin's self-government, but they remain the responsibility of the Minister for Energy, voivode and relevant operators, including the owners of electricity systems or electricity companies. Moreover, both the subject matter of functionality of individual facilities, installations, equipment and services making up this system, as well as plans for its protection constitute classified information ${ }^{31}$. In the light of the above, further reflections do not refer to specific tasks and undertakings in the field of protection of energy critical infrastructure. However, special attention was paid to the prevention of threats to citizens' life and health resulting from the disruption of the functioning of the energy CI system. Essentially, they focus on presenting the conclusions and recommendations in the field of actions to prevent potential secondary threats from the perspective of the bodies of Szczecin's territorial self-government.

Returning to the thread of the exercises codenamed "Energy 2018", based on a specific problem situation and the formulated general objective, the following specific objectives were set $^{32}$ :

1) checking the alert system of the City Crisis Management Team (CCMT) and the City Crisis Management Centre (CCMC) and checking the availability of both the Team members and the Centre members;

2) checking the feasibility of prepared crisis response procedures regarding the lack of electricity supply and cyber attacks ${ }^{33}$;

3) improving the skills of Centre members in taking actions aimed at providing effective assistance to the injured, stopping the development of a crisis situation and limiting the consequences of a lack of electricity supply;

${ }^{30}$ They are obliged to: prepare and implement, in accordance with the anticipated threats, plans for the protection of critical infrastructure and holding their own reserve systems to ensure security and to maintain the functioning of this infrastructure until it is fully restored; appoint a person responsible for maintaining contacts with entities competent for critical infrastructure protection; to inform immediately the Head of the Internal Security Agency about any terrorist threats to critical infrastructure; to cooperate in the creation and implementation of the National Critical Infrastructure Protection Program. More in: Ibidem, p. 16/48-17/48.

${ }^{31}$ See Article 5b section 6, section 7 subsection 1, section 8, Article 6b section 7 and Article 6c section 2 CMA.

${ }^{32} \mathrm{Cf}$. the above-mentioned Documentation of the urban exercise in the scope of crisis management codenamed "Energy 2018".

33 The occurrence of consequences of the cyber-attack carried out this day on among others IT systems of the Office of the City of Szczecin were also assumed. The actions taken by the IT Department of the Office of the City of Szczecin as part of the cyber-attack simulation were presented in detail in the Report on the exercise codenamed "Energy 2018" addressing "Operation of the City Crisis Management Team in the event of an electrical power failure" conducted on 19 March 2018, approved on 25 April 2018 by Piort Krzystek, President of the City of Szczecin. Available in the Department of Crisis Management and Civil Protection of the Office of the City of Szczecin and in the Research Workshop on the Safety of Self-governing Communities of the US Faculty of Humanities. 
4) checking the possibilities of using the infrastructure of the Interactive Centre for Communication and Social Research of the US Faculty of Humanities at ul. Krakowska 71-76 in Szczecin as a backup work place for the Team and the Centre.

For safety reasons, it was concluded that the most appropriate solution would be to carry out the exercises in the application formula - assuming that the operational time will not be parallel to the astronomical time ${ }^{34}-$ as part of the following stages ${ }^{35}$ :

1) Stage I (preliminary) - 22.02.2018: training the Team and the Centre members in the use of the infrastructure of the aforementioned work place, entitled "Tasks and organization of elements forming the city crisis management system. Characteristics of threats in the autumn-spring period";

2) Stage II (proper exercises) - 19.03.2018: checking the functioning of the Team's and the Centre's alert system;

3) Stage III - 19.03.2018 between 07:00-15:00: implementation of the response phase as part of crisis management by the Team's members;

4) Stage IV - 19.03.2018 between 15:00-15:30: discussing the exercise, including the presentation of the most important conclusions and the formulation of working tasks on their basis;

According to the adopted concept, the implementation of the exercise was based on the following event scenario: on 19 March 2018 at 5:05 due to a failure in the power system of northern Germany and Poland, the European energy system did not get balanced. As a result, there were a number of automatic cascade shutdowns of 400 and $220 \mathrm{kV}$ transmission lines, generators shutdowns in German and Polish system power plants and the division of the entire European system into asynchronous areas occurred. The north-western part of Poland, including the Szczecin agglomeration, was completely deprived of power supply. In addition, as a result of falling sleet and the accumulation of rime on transmission grids, some of the transmission and distribution lines were damaged in the above-described area ${ }^{36}$.

The following people took part in the exercise: members of the City Crisis Management Team, including - apart from directors of individual department of the Office of the City of Szczecin and poviat inspections - representatives of the Police, the State Fire Service and a representative of the Szczecin Branch of the Enea Operator Sp. Z o.o. Poznań. The Team's work was headed by Piotr Krzystek, the President of the City of Szczecin. The course of the exercise was recorded, and also each participant had an additional task to fill in, on an on-going basis, the "Work Sheet (...)" prepared for the needs of this exercise - (see annex). Moreover, a group of students of both undergraduate and postgraduate courses in Internal Security and the author were invited to be observers, who also shared their observations with the organizers.

A detailed account of the course of each stage of the exercise and its evaluation was presented in the aforementioned Report on the exercise codenamed "Energy 2018".

In the participants' assessment, both the main and detailed objectives of the exercise were achieved. Analysis of the content provided in, among others, the abovementioned

\footnotetext{
${ }^{34}$ According to the adopted concept, the failure and removing its effects lasted from 05:00 on 19 March till 12:30, whereas the exercises were carried out within one day, that is 19 March, from 05:00 till 15:30. More in: the above-mentioned Documentation of the urban exercise in the scope of crisis management codenamed "Energy 2018".

35 Ibidem. See also the aforementioned Report on the exercise codenamed "Energy 2018".

${ }^{36}$ Ibidem.
} 
worksheets, as well as direct observations of participants and observers made it possible to formulate the following conclusions and recommendations ${ }^{37}$ :

1) The lack of energy independence of key companies, institutions and municipal facilities affecting the safe functioning of the city of Szczecin is the main factor limiting the effectiveness of measures taken as part of crisis response, in conditions of a long-lasting electrical power failure. This condition is the result of the following irregularities and deficiencies:

- a significant part of the facilities important for the safety and security of the city and its residents is not equipped with power generators of adequate capacity nor do they have necessary energy connections;

- petrol stations in the territory of the city do not have alternative sources of power, as a result of which it is not possible to distribute fuels in the event of an electrical power failure;

- Enea Operator and other entities operating in the territory of the city have limited possibilities to make power generators available for crisis management purposes, which primarily results from the need to secure the implementation of their own tasks and the requirement to support other strategic recipients.

2) In the light of the weaknesses stated in point 1 it was concluded that the priority for the Municipality of the City of Szczecin is to obtain energy independence, at least to the extent ensuring the implementation of the main tasks for the safety and security of residents. In view of the above, the following were deemed necessary:

- examining energy independence of individual companies, institutions and municipal facilities, in particular those that are part of critical infrastructure;

- planning for and purchasing power generators of adequate capacity to equip schools designated to serve as support centres in crisis situations to residents and to key municipal companies and institutions;

- construction of the required power connections, according to uniform technical assumptions.

3) The priority is to ensure the continuity of work in the conditions of an electrical power failure in strategic services and trade, primarily in the field of fuel and food distribution or the possibility of withdrawals from cash machines.

4) It is necessary to widen the range of possibilities in terms of informing people in crisis situations. In particular, efforts should be made to ensure the continuity of broadcasting by Radio Szczecin, which is a key source of information for residents.

5) It is necessary to extend the fiber-optic network to schools - in the first place to the places designated as residents' support centres in crisis situations.

6) It is required to update and complete the City Crisis Management Plan in the security matrix ${ }^{38}$ and in the parts related to the following procedures:

a) "Activities in the face of an electrical power failure", as regards the designation of institutions, organizational units and companies, for which in the first place the following should be ensured:

- power from alternative sources of electricity;

\footnotetext{
${ }^{37}$ Cf. ibidem.
}

${ }^{38}$ Security matrix - a set of potential risks with an identification of the lead entity for their removal as well as cooperating entities. See Article 3 subsection 8 CMA. 
- power supply in the conditions of staged power restoration or in the event of limitations of available capacity;

b) "Actions in the face of a power system failure", in terms of:

- providing fuel for power generators and vehicles necessary to carry out activities under crisis management;

- solutions making it possible to inform residents about potential threats and support centres;

7) And others.

- creation of residents' support centres.

\section{CONCLUSION}

Formulating constructive conclusions and recommendations would not be possible without conducting the exercise codenamed "Energy 2018", which revealed numerous shortcomings both organizational and technical on the part of the energy system operator and the territorial self-government. The course of the discussed project, its assessment and the developed conclusions prove that one of the most desirable, practical and effective forms of testing crisis management plans - besides the necessity of verifying them under real threat conditions - are exercises. In addition, the implementation of this type of exercises is conducive to the education of officers of competent guards, services or inspections, as well as the society. Spreading knowledge and experience takes place not only thanks to direct relations of representatives of the academic community who take part in the exercises, but also through relevant publications.

And finally, it is appropriate to refer to the goal that the author of the publication had set and to the corresponding problematic situation implying the preparation of and conducting the exercise codenamed "Energy 2018". The analysis of publicly available documents ${ }^{39}$ and information from the President of the City of Szczecin's Plenipotentiary for Security, as well as author's personal direct observations allow the conclusion that experience resulting from actions under real threat conditions do certainly affect proactive measures of obliged entities in the event of an analogous situation. However, in the light of the above conclusions, it must be recognized that it is necessary to constantly improve the crisis management system in each of its elements and at each stage (prevention, preparation, response and reconstruction). Only in this way should the optimal level of its functioning be sought in the event of probable threats and their consequences.

\section{REFERENCES}

1. Działania obowiązanych podmiotów w sytuacji kryzysowej podczas masowej imprezy sportowej. Wymiar prawny, teoretyczny i praktyczny na przykładzie ćwiczenia dowódczo-sztabowego pod kryptonimem “Widzowie”, Guźniczak C. and Stempiński Sz. (eds.), Szczecin 2017.

2. Guźniczak C., Tuzimek P., Zapobieganie sytuacjom kryzysowym w nowoczesnych obiektach handlowo-ustugowych. Studium przypadku na przykładzie Centrum Handlowego "Galeria Kaskada" w Szczecinie [in:] Rola i zadania administracji publicznej w zarzadzaniu bezpie-

\footnotetext{
${ }^{39}$ I.a. Reports on the Status of the City of Szczecin for years: 2010, 2012, 2014 and 2016. Source:
} http://bip.um.szczecin.pl/chapter_11808.asp (access: 26.07. - 02.08.2018). 
czeństwem w Polsce, eds. Kisielnicki J., Płusa T., Rysz S. J., Rajchel J., Rajchel K., Rzeszów 2017.

\section{NEWSPAPER ARTICLES}

1. "Gigantyczna awaria rozłożyła cały Szczecin” [in:] "Expres Bydgoski” (daily), 9 April 2008 issue.

2. Inwestycje Enei Operator zminimalizowaty ryzyko powtórki szczecińskiego blackoutu [at:] portal cire.pl Centrum Informacji o Rynku Energii. Source: https://www.cire.pl/item, $161581,1,0,0,0,0,0$,inwestycje-enei-operator-zminimalizowaly-ryzyko-powtorki-szczecinskiego-blackoutu.html

3. Szczecin bez pradu! [in:] "Expres Ilustrowany" (daily), 9 April 2008 issue.

4. Szczecin bez pradu [in:] "Gazeta Wyborcza - Szczecin” (daily), 9 April 2008 issue.

5. Śnieg ciężki, jak ołów [in:] "Gazeta Wyborcza - Szczecin” (daily), 9 April 2008 issue.

\section{OTHER}

1. Documentation of the urban exercise in the scope of crisis management codenamed "Energy 2018”, approved on 7 March 2018 by Piotr Krzystek, President of the City of Szczecin. Available in the Department of Crisis Management and Civil Protection of the Office of the City of Szczecin and in the Research Workshop on the Safety of Self-governing Communities of the US Faculty of Humanities.

2. National Crisis Management Plan [Krajowy Plan Zarządzania Kryzysowego]. Source: http://rcb.gov.pl/krajowy-plan-zarzadzania-kryzysowego/

3. National Programme for Critical Infrastructure Protection [Narodowy Program Ochrony Infrastruktury Krytycznej]. Source: http://rcb.gov.pl/infrastruktura-krytyczna/, pp. 24/48-25/48

4. Report on the exercise codenamed "Energy 2018" addressing "Operation of the City Crisis Management Team in the event of an electrical power failure" conducted on 19 March 2018, approved on 25 April 2018 by Piort Krzystek, President of the City of Szczecin. Available in the Department of Crisis Management and Civil Protection of the Office of the City of Szczecin and in the Research Workshop on the Safety of Self-governing Communities of the US Faculty of Humanities.

5. Reports on the Status of the City of Szczecin for years: 2010, 2012, 2014 and 2016 [Raporty o Stanie Miasta Szczecin z lat: 2010, 2012, 2014 i 2016]. Source: http://bip.um.szczecin.pl/chapter_11808.asp

6. Stownik wyrazów obcych i zwrotów obcojęzycznych, Kopaliński W., 9th extended edition, Warszawa 1975.

\section{ACTS OF LAW}

1. Act of 10 April 1997 Energy law (consolidated text, Dz. U. of 2018 item 755 as amended).

2. Act of 26 April 2007 on crisis management (consolidated text, Dz. U. of 2017 item 209 as amended). 


\section{WEBSITES}

1. http://bip.um.szczecin.pl/chapter_11808.asp

2. http://buzz.gazeta.pl/buzz/56,163510,9829216,TOP_6_najwiekszych_blackoutow_w_historii__Miliony.html

3. http://rcb.gov.pl/infrastruktura-krytyczna/, s. 24/48-25/48

4. http://rcb.gov.pl/krajowy-plan-zarzadzania-kryzysowego/

5. https://www.cire.pl/item,161581,1,0,0,0,0,0,inwestycje-enei-operator-zminimalizowalyryzyko-powtorki-szczecinskiego-blackoutu.html

6. https://www.money.pl/gospodarka/wiadomosci/artykul/blackout-w-polsce-tchorzewski, $37,0,2367781 . h t m l$

Annex

NOTE

Szczecin, 19 March 2018

Fill out using a text editor or by hand using a ballpoint or a pen

(represented institution)

(function in the event of practiced crisis situation/team member)

WORKSHEET

for participants of exercises codenamed "Energy 2018"

\begin{tabular}{|c|c|c|c|c|}
\hline No. & $\begin{array}{l}\text { Date and time: } \\
\text { of receiving in- } \\
\text { formation about } \\
\text { the incident, } \\
\text { of receiving or } \\
\text { giving an in- } \\
\text { struction, } \\
\text { of actions, ac- } \\
\text { tivities taken, } \\
\text { etc. }\end{array}$ & $\begin{array}{l}\text { 1) Characteristics of the incident (what, } \\
\text { where, when, effects, etc.) } \\
\text { 2) Formulated conclusions from the } \\
\text { perspective of the represented insti- } \\
\text { tution as to the type of the incident, } \\
\text { including the risk of occurrence of } \\
\text { secondary threats and their conse- } \\
\text { quences, as well as the necessary } \\
\text { forces and resources. } \\
\text { 3) Hierarchically ordered targets to be } \\
\text { achieved and tasks to be carried out } \\
\text { in the context of the overall situation } \\
\text { as well as incidents. } \\
\text { 4) Received instructions (their content } \\
\text { and giver). } \\
\text { 5) Given instructions (their content and } \\
\text { addressee). }\end{array}$ & $\begin{array}{l}\text { Undertaken ac- } \\
\text { tions, the man- } \\
\text { ner of carrying } \\
\text { out activities } \\
\text { and tasks, in- } \\
\text { cluding those } \\
\text { that were com- } \\
\text { missioned. }\end{array}$ & $\begin{array}{l}\text { Notes on individual } \\
\text { stages of activities and } \\
\text { the implementation of } \\
\text { tasks. Possible difficul- } \\
\text { ties, including those re- } \\
\text { lating to: cooperation } \\
\text { with other entities, in- } \\
\text { adequacies of forces } \\
\text { and resources, organi- } \\
\text { zation of communica- } \\
\text { tion, out-of-date func- } \\
\text { tional annexes of the } \\
\text { master plan (to what } \\
\text { extent?) etc. }\end{array}$ \\
\hline 1. & 2. & 3. & 4. & 5. \\
\hline
\end{tabular}




\section{PRZECIWDZIAŁANIE SKUTKOM DLUGOTRWAŁEJ AWARII ENERGETYCZNEJ NA OBSZARZE DUŻYCH MIAST. STUDIUM PRZYPADKU NA PRZYKŁADZIE GMINY MIASTO SZCZECIN}

Intencją autora jest ukazanie wpływu doświadczeń płynących z konkretnej sytuacji kryzysowej i wywołanych nią skutków - w szczególności długotrwałego i rozległego braku energii elektrycznej - na działania obowiązanych podmiotów w zakresie zapobiegania takim zagrożeniom, jak również przygotowania się do reagowania na wypadek ich zaistnienia. Ze względu na określony w tytule przedmiot badań, rozważania autora koncentrują się na aktywności organów Gminy Miasto Szczecin oraz kooperacji z innymi podmiotami na rzecz zapobiegania wybranym zagrożeniom, ze szczególnym uwzględnieniem następstw rozległej awarii energetycznej. Artykuł zawiera odniesienia do obowiązujących przepisów prawa oraz oficjalnych dokumentów dotyczących kompetencji i zadań, które są przypisane tymże organom w ramach zarządzania kryzysowego, w tym ochrony infrastruktury krytycznej. Wiele uwagi poświęcono przede wszystkim zagadnieniom dotyczącym organizowania, prowadzenia i koordynowania szkoleń i ćwiczeń z zakresu zarządzania kryzysowego z udziałem przedstawicieli różnych podmiotów oraz środowisk, także akademickiego. Głównie, zaprezentowano wnioski i rekomendacje sformułowane na podstawie zrealizowanego 19 marca 2018 r. ćwiczenia: „Działanie Miejskiego Zespołu Zarządzania Kryzysowego w sytuacji awarii energetycznej, pod krypt. Energia 2018”. Przygotowanie i przeprowadzenie powyższego ćwiczenia wynikało z potrzeby wyjaśnienia sytuacji problemowej wyrażonej w formie następującego pytania: czy zmierzenie się z rzeczywistymi skutkami blackout-u (dotyczy szczecińskiego blackout-u z 8 kwietnia 2008 r.) wptywa na zmiany jakościowe w zakresie przygotowania się obowiązanych podmiotów na wypadek wystapienia podobnej sytuacji kryzysowej?

Słowa kluczowe: zarządzanie kryzysowe, infrastruktura krytyczna, awaria energetyczna, samorząd terytorialny, Gmina Miasto Szczecin.

DOI: $10.7862 /$ rz.2018.mmr.42

Tekst złożono do redakcji: wrzesień $2018 \mathrm{r}$.

Tekst przyjęto do druku: grudzień 2018 r. 